\title{
EXPERIMENTAL STUDY OF BRACKISH WATER DISTILLATION IN SINGLE SLOPE SOLAR STILL USING SENSIBLE HEAT STORAGE MATERIALS
}

Lenin RAVICHANDRAN, Department of Heat and Power Engineering Systems, Riga Technical University, Viskalu 6, LV-1006, Riga, Latvia, lenin1994.in@gmail.com

Dmitrijs RUSOVS, Department of Heat and Power Engineering Systems, Riga Technical University, Viskalu 6, LV-1006, Riga, Latvia, dmitrijs.rusovs@rtu.lv (corresponding author)

Thottipalayam Vellingri ARJUNAN, Department of Mechanical Engineering, Coimbatore Institute of Engineering and Technology, Coimbatore-641109, India, arjun_nivi@yahoo.com

Selvaraj VIJAYAN, Department of Mechanical Engineering, Coimbatore Institute of Engineering and Technology Coimbatore 641109 India, vinsel@gmail.com

Murugesan MATHESWARAN, Mechanical Engineering Department, Johnson Institute of Technology, Coimbatore, India, madhume01@gmail.com

\begin{abstract}
Solar distillation is one of the important methods of getting clean water from brackish and seawater using the renewable energy of the sun. The passive type solar still represent most economical method to supply drinking water for domestic applications for decentralized level. Experimental measurements of solar distillation productivity for single slope still were conducted at the testing field of the Mechanical Engineering department, Coimbatore Institute of Engineering and Technology, Coimbatore, Tamilnadu, India. The influence of basin water quantity and amount of energy storage materials are examined and the performance is compared. The target of this research is to find best way to keep the excess heat by energy storage materials and release it during off-sunshine hours for increment in distillate output and efficiency. Various sensible heat energy storage materials like pebbles, blue metal stone, red brick, granites and white marbles were used as energy storage medium. The daily yield of black granite still is higher than other energy storage material stills and is equal to $3.216 \mathrm{~kg} / \mathrm{day} / \mathrm{m}^{2}$, which is $29 \%$ higher than that of the still without energy storage materials.
\end{abstract}

Keywords: fresh water, passive still, solar distillation, energy storage material.

\section{INTRODUCTION}

Supplying fresh and healthy water is one of the major problems in different parts of the world, especially in arid remote areas. The solar distillation represents the important methods of getting clean water from brackish and seawater using the free energy supply from the sun. Solar distillation in solar still are cheap and have the simple technology; hence low maintenance expenses are required and can be placed at each house for producing at least drinking water. The problem of solar stills is the low productivity.

There are a lot of papers devoted to consideration of solar still design influence on the performance of distillation (Arjunan et. al., 2014; Deshmukh and Thombre, 2017; Rabhi et al., 2017; Himanshu and Mahesh, 2017; Patel and Kumar, 2016; Gugulothu et al., 2017; Sharshir et al., 2017; Shashikanth et al., 2015). Most of these research work done on the solar stills was directed towards the achievement of the highest possible efficiency. Solar intensity value is very high in mid and afternoon hours. During this period the available energy for converting fresh water is surplus than required and is going to the atmosphere as heat loss. Storing of this excess heat may improve the performance of solar still when the stored heat release to the basin water in the evening and night time. In this direction many researchers are working by using various absorbing materials to store excess heat energy in solar stills during the daytime for the continuation of the process at late evening and night hours. Experimental study show that black granite gravels are more efficient than pebbles and blue metal stone, when used as energy storage material for enhancement of solar still performance (Arjunan et al., 2014). The rate of production of desalinated water in solar still varies from $2 \mathrm{~L} /$ day to $12 \mathrm{~L} /$ day and the efficiency varies from $20 \%$ to $80 \%$ which depends on the design parameters [5].

The distillate output of a single slope solar still was analyzed with sand and servotherm medium oil (heat transfer oil) as passive storage material beneath the basin liner (Deshmukh and Thombre, 2017). They found that sand and

Copyright (C) 2017 The Authors. Published by Aleksandras Stulginskis University. This is an open-access article distributed under the terms of the Creative Commons Attribution License (CC-BY 4.0), which permits unrestricted use, distribution, and reproduction in any medium, provided the original author and source are credited. 
Servotherm medium oil, lower storage depths yield higher output compared to conventional still. Also, with passive storage, overnight yield was found enhanced while daylight productivity lowered. Phase change materials such as potassium dichromate $\left(\mathrm{K}_{2} \mathrm{Cr}_{2} \mathrm{O}_{7}\right)$, magnesium sulphate heptahydrate $\left(\mathrm{MgSO}_{4} 7 \mathrm{H}_{2} \mathrm{O}\right)$ and sodium acetate $\left(\mathrm{CH}_{3} \mathrm{COONa}\right)$ were used as energy absorbing materials in solar desalination system. Among these phase change materials, $\left(\mathrm{MgSO}_{4} 7 \mathrm{H}_{2} \mathrm{O}\right)$ gives better productivity of potable water (Gugulothu et al., 2017). A cumulative distillate output of 3.492 $1 / \mathrm{m}^{2}$ is recorded for the solar still with pin fins absorber and condenser compared to $2.38-2.471 / \mathrm{m}^{2}$ for conventional still (Rabhi et al., 2017).

The water quantity or water depth is also influencing the performance of solar still. Increase in the water depth will cause decrease the distillate production of the still up to depths of about $10 \mathrm{~cm}$, but for depth of water more than 0.1 $\mathrm{m}$ it becomes constant. Average distillate output reported for solar still with the effective area of $0.25 \mathrm{~m}^{2}$ is $2.011 / \mathrm{m}^{2}$ and $1.88 \mathrm{l} / \mathrm{m}^{2}$ at water depths $4 \mathrm{~cm}$ and $6 \mathrm{~cm}$ respectively (Himanshu and Mahesh, 2017).

The literature survey briefly references that the research on the solar distillation system is highly persuaded towards the passive solar stills (Sharshir et al., 2017; Shashikanth et al., 2015). Based on the observations made and research gaps identified during the literature survey, the presented experimental research was directed to following:

$\checkmark$ to apply Taguchi method for design of experiments by selection of set parameters for solar distillation and collect data about the effect of different energy storage materials on the performance of single slope still,

$\checkmark$ to find and test best set of parameters like water quantity, type and quantity of energy storage materials with purpose to enhance solar still output,

$\checkmark$ to create description of solar distillation productivity depending on energy storage materials parameters,

$\checkmark$ to evaluate relative significance of the process control parameters and their contribution in the distilled output,

$\checkmark$ to estimate the quality of still process by of TDS (total dissolved solids) measurement for brine and distillate.

\section{EXPERIMENTAL SETUP}

The experimental system involves six identical single slope single basin solar stills with same dimensions. The basin liner area of $0.25 \mathrm{~m}^{2}$, is made of the galvanized iron sheet with $1.4 \mathrm{~mm}$ thickness. Basin surfaces are painted with black paint to absorb the maximum amount of solar radiation. The still cover made of window glass with thickness $4 \mathrm{~mm}$ and tilted by $11^{\circ}$ with horizontal. Glass cover is framed with wood and sealed with silicone rubber. A collecting trough made by G.I. sheet is used in the still to collect distillate condensing on the inner surfaces of the glass covers and to pass the condensate to a collecting flask. Steel rule is fixed along with the inner wall for measuring water levels. The bottom and sides are insulated with glass wool. Schematic and pictorial views of the experimental setup are shown in Figure 1 and Figure 2 respectively. The experiments are carried out during the month of April 2017 in two phases at the testing field of the Mechanical Engineering Department, Coimbatore Institute of Engineering and Technology, Coimbatore, Tamilnadu, India. First phase the experimental study conducted with different energy storage material with the constant mass of material and water to find the effect of energy storage materials on the performance of solar still. During the second phase the experiments are conducted based on the Taguchi design of experiments with different parameters.

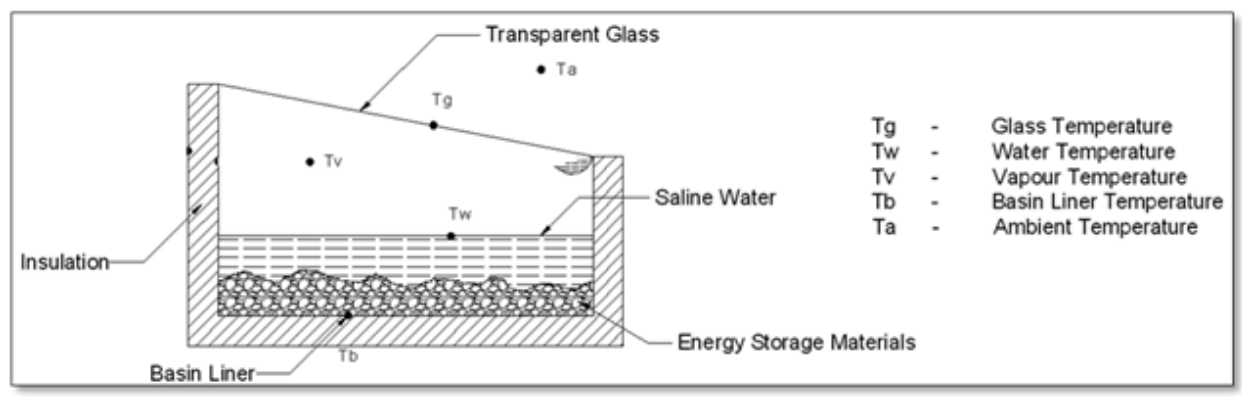

Figure 1. Schematic of experimental setup

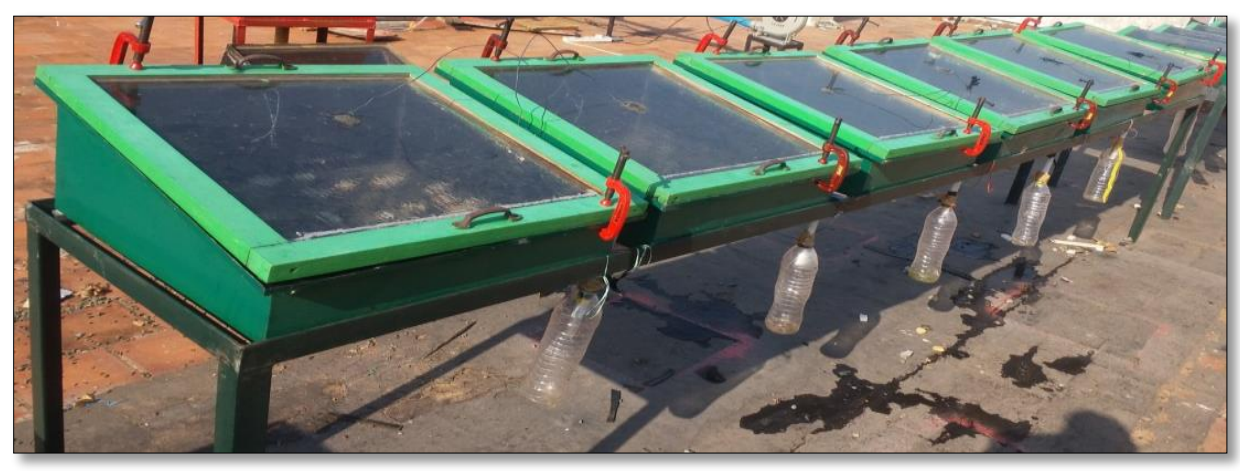

Figure 2. Pictorial view of experimental setup 
The properties of energy storage materials used for this experimental study are given in Table 1 . These materials are readily available with low cost. The temperature of different components was measured from morning 9.00 hrs. to evening $18.00 \mathrm{hrs}$. by using the K-type thermocouple that is connected to all the parts such as glass cover, basin liner with energy storage materials and vapor temperature. These temperatures are indicated by means of a digital temperature indicator.

Table 1. The properties of energy storage materials used

\begin{tabular}{|l|c|c|c|c|}
\hline \multicolumn{1}{|c|}{ Material } & Density, kg/m3 & $\begin{array}{c}\text { Specific heat, } \\
\mathrm{J} / \mathrm{kg} \mathrm{K}\end{array}$ & $\begin{array}{c}\text { Thermal Conductivity, } \\
\mathrm{W} /(\mathrm{m} \mathrm{K})\end{array}$ & $\begin{array}{c}\text { Emissivity-Coefficients } \\
\varepsilon\end{array}$ \\
\hline Pebble & 2630 & 775 & 2.8 & $0.50-0.60$ \\
\hline Red Bricks & $1500-1800$ & 840 & $0.9-1.2$ & $0.74-0.93$ \\
\hline $\begin{array}{l}\text { Blue Metal } \\
\text { (coarse aggregate) }\end{array}$ & $1520-1680$ & 840 & 1.6 & $0.90-0.95$ \\
\hline Black Granite & $2600-2800$ & 820 & $1.7-3.9$ & 0.45 \\
\hline White Marble & $2600-2800$ & 880 & 2.5 & 0.95 \\
\hline
\end{tabular}

\section{TAGUCHI METHOD FOR OPTIMIZING SOLAR STILL}

Taguchi method is being extensively recognized and used by the researchers and industrialists to design the experiments based on orthogonal arrays to optimize the process parameters with a minimum number of experiments. The quality characteristics of the single slope solar still can be studied with the amount of water distilled per day. Here, the amount distilled water produced must be greater, hence the quality characteristic carefully chosen for the optimization is 'larger the better'. The following steps are involved in the application of Taguchi method to the optimization of solar still performance

$\checkmark$ Identification of process parameters and their levels that influencing the distillate output of the single slope solar still with energy storage material;

$\checkmark$ Selection of suitable orthogonal array to perform the design of experiments;

$\checkmark$ Conducting the experiments per DoE (design of experiment) represented in Table 2;

$\checkmark$ Performing a statistical analysis of variance (ANOVA) to identify the significant parameters

\section{RESULTS AND DISCUSSIONS}

The hourly variations of water temperatures in still are compared for Conventional solar still (without energy storage materials) and solar still with energy storage materials presented in Figure 3. Effects of different energy storage materials resulted in larger differences in the temperature of the still components. It is observed that in energy storage material stills, the considerable amount of heat is stored by the storage materials during the morning hours and the heat is released into the water in the late afternoon hours when radiation is low. This may be the reason for the components of the energy storage material stills to attain low temperature during the morning hours and increased temperature during the evening hours. However, in the solar still without energy storage material, due to the absence of storage medium, the components attain higher temperature from morning to noon and it cools down rapidly during the late evening hours.

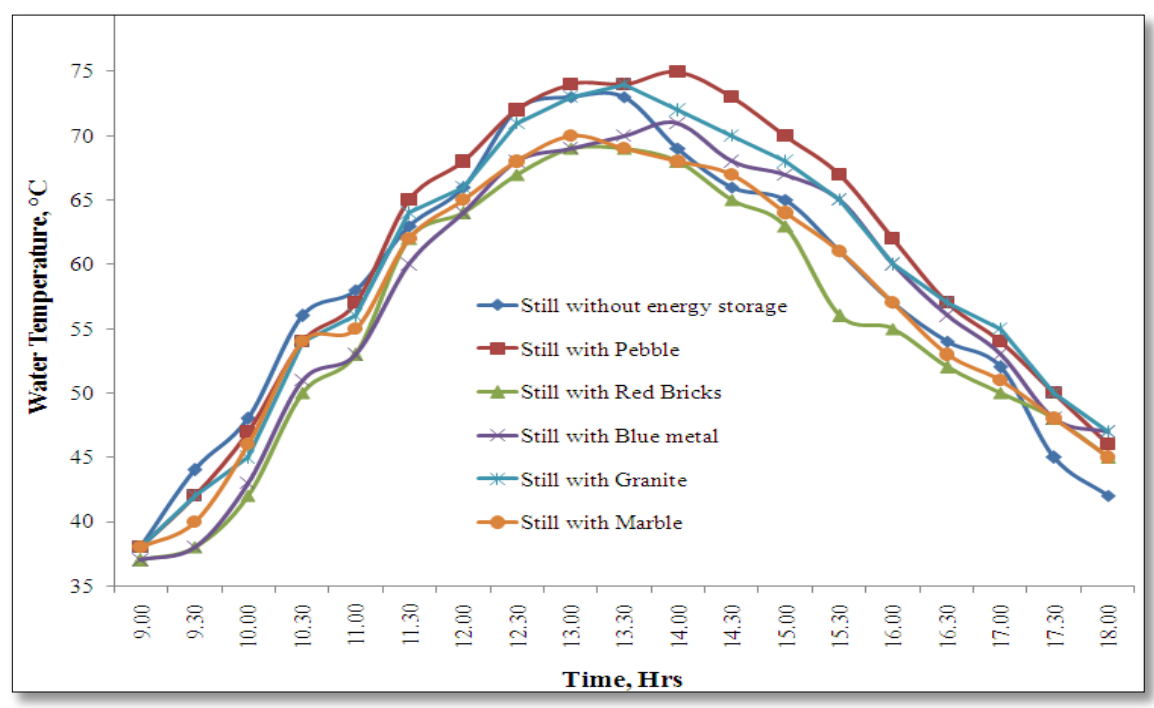

Figure 3. Hourly variations of water temperatures for different energy storage materials 
The condensation occurs at the glass bottom surface due to heat transfer from the air-vapor mixture to the atmosphere. Hence temperature difference between water and glass is an important parameter in view of higher production rate. The hourly variations in the temperature difference between water and glass for the different energy storage materials given in Figure 4. It clearly indicates that in the black granite still the temperature difference between water and the glass $(\Delta \mathrm{T})$ is higher than other solar stills during 13:00 hrs. - 18:00 hrs. This may be the reason for higher output during this period, whereas in the still without energy storage materials, this difference is high in the morning hours (9:00 hrs. - 12:00 hrs.)

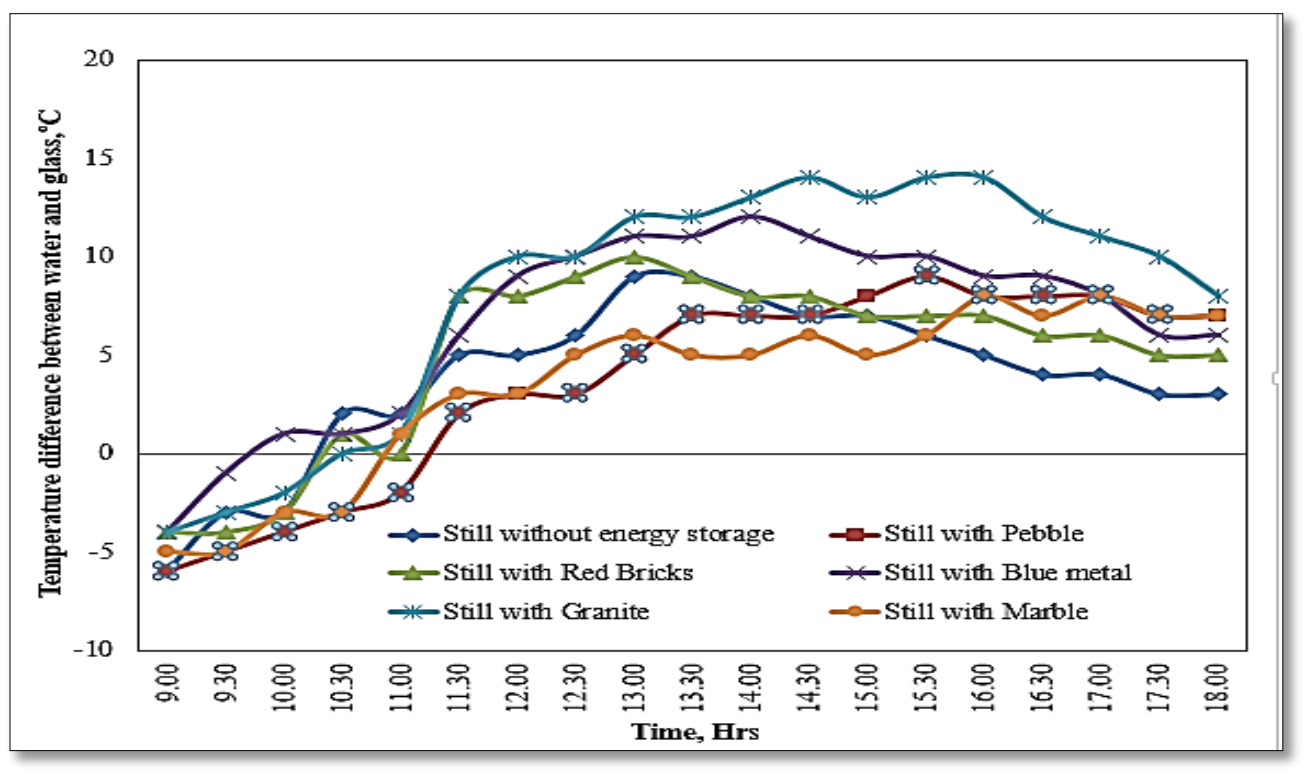

Figure 4. Hourly variations of temperature difference between water and glass for different energy storage materials still.

\section{YIELD AND DISTILLED OUTPUT}

The yield of a solar still indicates the amount of water produced by the still. The freshwater yield of the solar still can be measured with a measuring jar on the hourly basis. Then, the overall yield can be calculated for a day based on the hourly yield of the solar still. The hourly distillate yield $\left(\mathrm{m}_{\mathrm{w}}\right)$ is function of the evaporative heat transfer coefficient and temperature difference between the water surface and glass cover inner surface.

Distillate output from 18.00 to 9.00 (of next day) represents night still performance due to heat consumption from energy storage material. It is obvious that granite had best property combination that ensures highest daily yield for solar still output $3.216 \mathrm{~kg} / \mathrm{day} / \mathrm{m}^{2}$, ) which is $29 \%$ higher than the output of the still without energy storage materials.

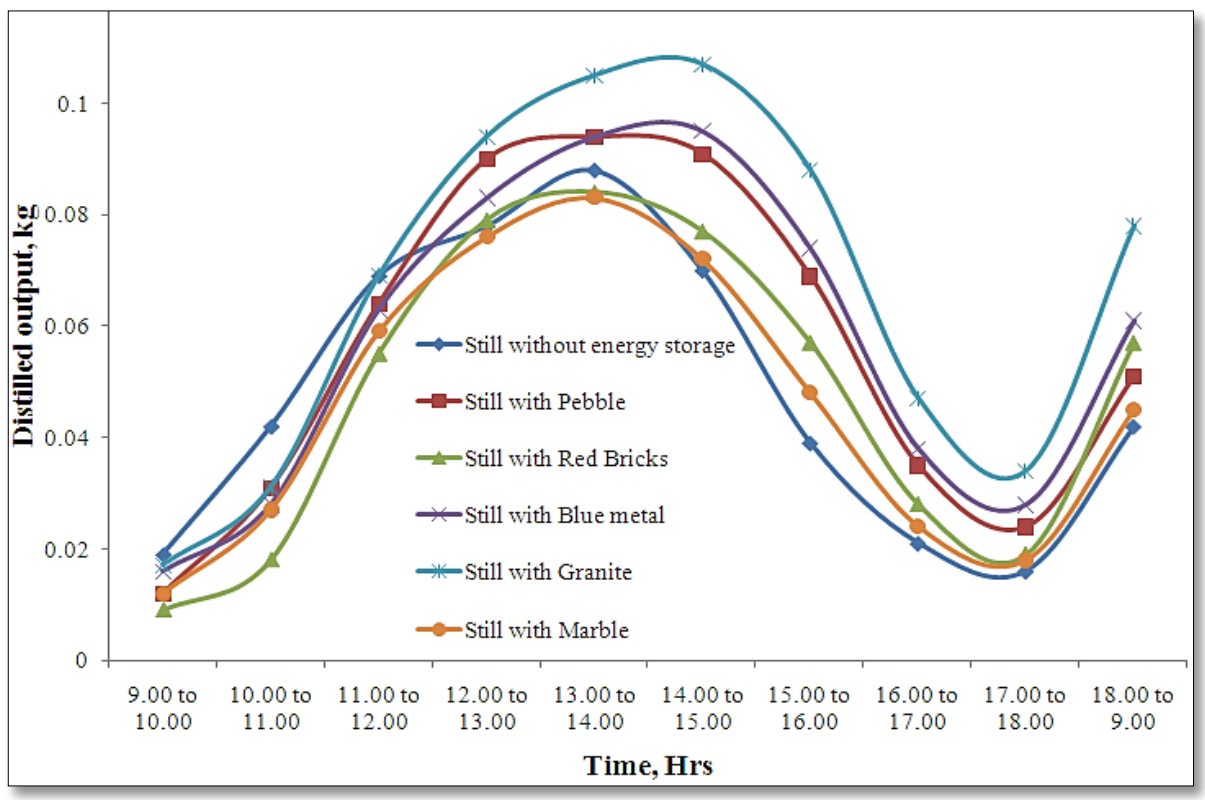

Figure 5. Hourly yield of distillate in solar still. 
Table 2. The design of experiments for the orthogonal array with experimental results for daily yield

\begin{tabular}{|c|c|c|c|c|c|}
\hline \multirow[b]{2}{*}{$\begin{array}{l}\text { Ex. } \\
\text { No. }\end{array}$} & A & B & $\mathrm{C}$ & $\mathrm{D}$ & \multirow[b]{2}{*}{$\begin{array}{l}\text { Productivity in } \mathrm{ml} / \\
\mathrm{m}^{2}\end{array}$} \\
\hline & $\begin{array}{c}\text { Water } \\
\text { Quantity }\end{array}$ & $\begin{array}{c}\text { Sensible heat storage } \\
\text { material }\end{array}$ & $\begin{array}{c}\text { Size of the } \\
\text { material }\end{array}$ & $\begin{array}{c}\text { Quantity of the } \\
\text { material }\end{array}$ & \\
\hline 1 & $10 \mathrm{~mm}$ & Pebble & $5-15 \mathrm{~mm}$ & $1.0 \mathrm{~kg}$ & 2928 \\
\hline 2 & $10 \mathrm{~mm}$ & Black Granite & $15-25 \mathrm{~mm}$ & $1.5 \mathrm{~kg}$ & 3032 \\
\hline 3 & $10 \mathrm{~mm}$ & Blue Metal Stone & $25-35 \mathrm{~mm}$ & $2.0 \mathrm{~kg}$ & 3104 \\
\hline 4 & $10 \mathrm{~mm}$ & White Marble & $35-50 \mathrm{~mm}$ & $2.5 \mathrm{~kg}$ & 2872 \\
\hline 5 & $20 \mathrm{~mm}$ & Pebble & $15-25 \mathrm{~mm}$ & $2.0 \mathrm{~kg}$ & 2904 \\
\hline 6 & $20 \mathrm{~mm}$ & Black Granite & $5-15 \mathrm{~mm}$ & $2.5 \mathrm{~kg}$ & 3056 \\
\hline 7 & $20 \mathrm{~mm}$ & Blue Metal Stone & $35-50 \mathrm{~mm}$ & $1.0 \mathrm{~kg}$ & 2964 \\
\hline 8 & $20 \mathrm{~mm}$ & White Marble & $25-35 \mathrm{~mm}$ & $1.5 \mathrm{~kg}$ & 2868 \\
\hline 9 & $30 \mathrm{~mm}$ & Pebble & $25-35 \mathrm{~mm}$ & $2.5 \mathrm{~kg}$ & 2984 \\
\hline 10 & $30 \mathrm{~mm}$ & Black Granite & $35-50 \mathrm{~mm}$ & $2.0 \mathrm{~kg}$ & 3124 \\
\hline 11 & $30 \mathrm{~mm}$ & Blue Metal Stone & $5-15 \mathrm{~mm}$ & $1.5 \mathrm{~kg}$ & 3100 \\
\hline 12 & $30 \mathrm{~mm}$ & White Marble & $15-25 \mathrm{~mm}$ & $1.0 \mathrm{~kg}$ & 2860 \\
\hline 13 & $40 \mathrm{~mm}$ & Pebble & $35-50 \mathrm{~mm}$ & $1.5 \mathrm{~kg}$ & 2924 \\
\hline 14 & $40 \mathrm{~mm}$ & Black Granite & $25-35 \mathrm{~mm}$ & $1.0 \mathrm{~kg}$ & 2944 \\
\hline 15 & $40 \mathrm{~mm}$ & Blue Metal Stone & $15-25 \mathrm{~mm}$ & $2.5 \mathrm{~kg}$ & 2880 \\
\hline 16 & $40 \mathrm{~mm}$ & White Marble & $5-15 \mathrm{~mm}$ & $2.0 \mathrm{~kg}$ & 2816 \\
\hline
\end{tabular}

To confirm the selected optimum parametric setting, the experimental study has been conducted with given below Water quantity $\quad: 7.5$ liters $-3 \mathrm{~cm}$ depth

Material

: Black granite

Size

: $25-35 \mathrm{~mm}$

Quantity of material : $2.0 \mathrm{~kg}$

The experimental study confirmed that the optimum parameters yield the distillate output of $3124 \mathrm{ml} / \mathrm{m}^{2}$, which is higher than the distillate output in other settings. The water depth, in this case, is $30 \mathrm{~mm}$ and material thickness (average quantity in $\mathrm{kg}$ divided by density and area of still) is about $25 \mathrm{~mm}$. In case of the size of black granite had similar value to water depth some granite pieces can be above the water surface. Therefore, small water depth 10-20 mm will not cover all solid particle with big size and it will decrease evaporation surface of the water and reduce distillation output for different water depth in still for black granite.

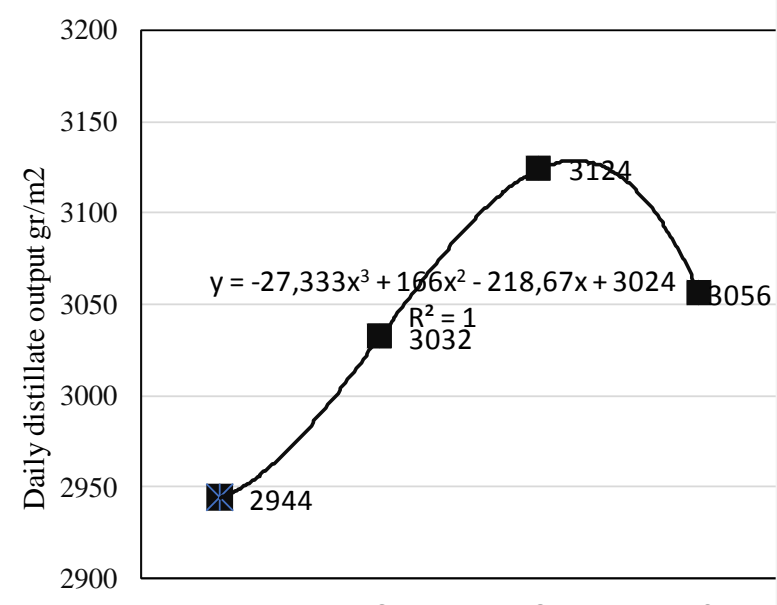

Amount of black grănite per unit ${ }^{8}$ of still bottom

Figure 7. Daily yield of distillate in solar still for black granite

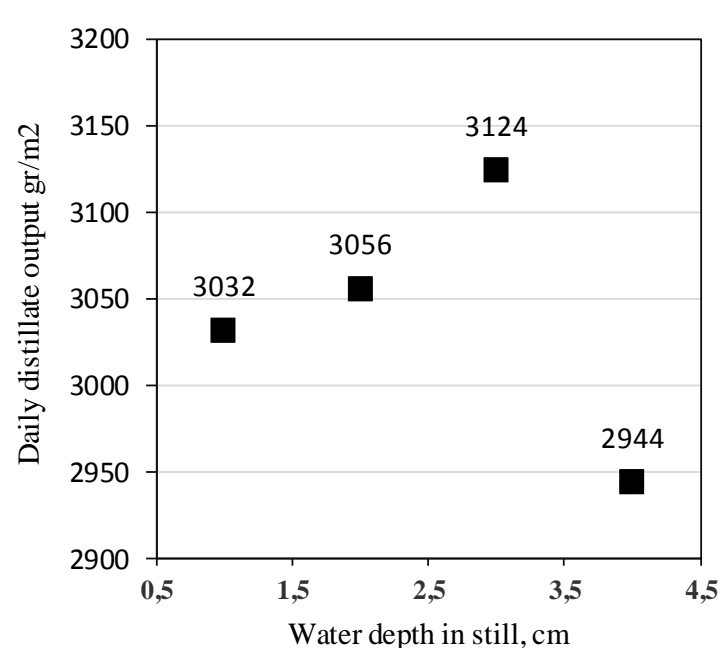

Figure 6. Daily yield of distillate in solar still

Presented experimental data for still performance for different amount of energy storage material is determined by the progressive relationship

$$
D=-27,333 M^{3}+166 M^{2}-218,67 M+3024, \quad R^{2}=1
$$


where: $\mathrm{D}$ - distillate output in $\mathrm{ml} /\left(\mathrm{m}^{2}\right.$ day) per day, $\mathrm{M}$ - the amount of granite in $\mathrm{kg} / \mathrm{m}^{2}$ in the still bottom. This equation is valid for water depth in still from 1 to $4 \mathrm{~cm}$.

\section{ANALYSIS OF VARIANCE (ANOVA)}

Analysis of variance was performed on signal-to-noise ratios to find the relative significance of the process control parameters and their contribution in the process performance. The Figures 6 and 7 show the contribution of parameters on the performance of the solar still with energy storage materials. The amount and type of sensible heat storage materials play a significant role in determining the performance of the solar still, the reason may be the specific heat capacity of the material. The next significant parameter considered is of water quantity in the basin. The less significant parameter is of the size of the material among all other parameters considered for the optimization in table 2.

\section{THE SOLAR STILL DISTILLATE QUALITY}

In arid, semi-arid and coastal areas plenty of underground water is available, but it is highly saline (TDS - total dissolved solids $\mathrm{mg} / \mathrm{l}$ from $2000 \mathrm{ppm}$ to $3500 \mathrm{ppm}$ ) composed of dissolved salts and therefore, unfit for human consumption. The maximum level of acceptance of salt content in fresh water for human consumption is $500 \mathrm{ppm}$. The condensate produced by the solar stills had TDS less than $100 \mathrm{mg} /$ liter in comparison to 2700 (for brine). When the water is used for drinking purposes, this will have to be mixed with saline water so that the TDS meets the mineral requirements of the human body.

\section{CONCLUSIONS}

- The black granite gravels are the most suitable energy storage medium for productivity improvement in a typical solar still it gives the higher yield than other tested energy storage material. Output with black granite gravels is equal to $3.216 \mathrm{~kg} / \mathrm{day} / \mathrm{m}^{2}$, which is $29 \%$ higher than that of the conventional still without energy storage materials.

- The solar still with the energy storage material are collecting a considerable amount of heat during the late morning hours and this heat is released into the water in the late afternoon hours when radiation is low. The temperature difference between water and the glass $(\Delta \mathrm{T})$ is high in the still with black granite. The effects of different energy storage materials resulted in larger differences in the temperature of the still components.

- The productivity during the night time is high in the solar still with energy storage materials if compared to conventional still. However, the excess amount of energy storage material will slow down warming up and distillate output during early morning hours and will decrease daily production rate. Therefore, storage material quantity threshold for efficient use of still was experimentally observed.

- The design of experiment by Taguchi method was used for data collection. New empirical equation for description of distillation output depending on granite gravels quantity in still presented in paper.

- The gravels amount and water quantity can be considered as main control parameters for distillation process and optimum parametric setting (gravel and water amount) for still was presented and tested.

- Solar distillation in experimental measurement show decrease of brine TDS from 2700 to $100 \mathrm{mg} / \mathrm{liter}$ in distillate. The quality of demineralization is sufficient for production of drinking water.

\section{REFERENCES}

1. Arjunan, T. V., H. S. Aybar, P. Sadagopan, B., Chandran S, Neelakrishnan, S., Nedunchezhian, N. 2014. The Effect of Energy Storage Materials on the Performance of Simple Solar Still,. Energy Sources, Part A: Recovery, Utilization, and Environmental Effects, Vol: 36, pp. 131-141.

2. Deshmukh, H.S., Thombre, S.B. 2017. Solar distillation with single basin solar still using sensible heat storage materials. Desalination, Vol. 410, pp. 91-98. https://doi.org/10.1016/j.desal.2017.01.030

3. Rabhi, K., Nciri, R., Nasri F., Ali, C., Bacha, H. B. 2017. Experimental performance analysis of a modified single-basin singleslope solar still with pin fins absorber and condenser. Desalination, Vol. 416, pp. 86-93. https://doi.org/10.1016/j.desal.2017.04.023

4. Himanshu, M., Mahesh, K. 2017. Performance analysis of single basin solar distillation cum drying unit with parabolic reflector. Desalination, Vol. 416. pp. 1-9. https://doi.org/10.1016/j.desal.2017.04.020

5. Patel, P., Kumar, R. 2016. Comparative Performance Evaluation of Modified Passive Solar Still Using Sensible Heat Storage Material and Increased Frontal Height. Procedia Technology, Vol. 23, pp. 431-438. https://doi.org/10.1016/j.protcy.2016.03.047

6. Gugulothu R.,. Somanchi N. S, Devendar, G., Kaluriand P., Deepika N. 2017. Solar Water Distillation Using Different Phase Change Materials. Materials Today: Proceedings, Vol. 4, Iss. 2, Part A, pp. 314-321.

7. Sharshir, S.W., Elsheikh A.H., Guilong Peng, Nuo Yang, Kabeel, A.E. 2017. Thermal performance and exergy analysis of solar stills - A review. Renewable and Sustainable Energy Reviews, Vol. 73, pp. 521-544. https://doi.org/10.1016/j.rser.2017.01.156

8. Shashikanth, M., Khadka B., Lekhana Y., Kiran, M.S.P., Veerammneni S.. 2015. Solar water distillation using Energy storage. Procedia Earth and Planetary Science, Vol. 11, pp. 368-375. https://doi.org/10.1016/j.proeps.2015.06.074

9. Shukla, A., Kant, K., Sharma, A.. 2017. Solar still with latent heat energy storage: A review. Innovative Food Science \& Emerging Technologies, Vol. 41, pp.34-46. https://doi.org/10.1016/j.ifset.2017.01.004 